\title{
THE IMPACT OF HIGH-PERFORMANCE WORK SYSTEMS ON EMPLOYEE ENGAGEMENT: THE MODERATING ROLE OF ORGANIZATIONAL JUSTICE
}

\author{
Emmanuel Oppong Peprah \\ Capital University of Economics and Business, Beijing, China \\ opek3@yahoo.com
}

\begin{abstract}
Purpose - This paper investigates the impact that High-Performance Work Systems (HPWS) have on Employee Engagement and the moderating effect of Organizational Justice on this relationship.

Research methodology - By the usage of a quantitative research method, data gathered from 251 employees of Professional Service firms are analysed with SPSS.

Findings - This study found that there is a positive relationship between HPWS and Employee Engagement. It also found that Organizational Justice moderates the relationship between the two.

Research limitations - Data was only gathered at the employee level making the interpretation of HPWS to be how employees perceive it. Hence a further study at the firm level as well as cross-sectional analyses will be needed in the future.

Practical implications - Management of firms should avoid a 'one-size-fits-all' approach in the administration of HR policies and should rather encourage tailor-made treatment for individual employees of the firm. Unfairness is encouraged if the firm is after employee engagement.

Originality/Nalue - This study is one of the first to investigate the moderating effect of organizational justice on the relationship between HPWS and employee engagement and the first to advice firm managers to be unfair in their dealings with individual employees.
\end{abstract}

Keywords: Employee Engagement, High-Performance Work Systems, Organizational Justice.

\section{INTRODUCTION}

The combination of effective Human Resource (HR) practices is a key ingredient for the success of a company. High-Performance Work Systems (HPWS) is therefore the concept which highlights such a combination to operationalize HR practices and ensure efficiency (Wu et al., 2015). HPWS are seen as generating value for an organization by cutting costs, improving productivity and creating value for employees as well. There is currently not one agreed HPWS definition. However, common concepts found in the definitions given by other authors include the 'focusing on investment in people, 
empowerment of employees, effective communication systems, job security, fair pay environment, low status differentials, performance management, and promotion on merit lines' (Demirbag et al., 2014).

There are quite a number of variables that researchers have proposed that HPWS can lead to. Among them is employee engagement (Regy \& Malini, 2019). According to Bal et al. (2013) greatly engaged employees are passionate about their work and deeply associate themselves to their business, whereas disengaged employees do not exhibit these qualities and feelings. Additionally, engaged employees contribute substantially to team efficiency and are a potential source of broad competition and strategic advantage for their employers. Furthermore, engaged employees are creative (Sahoo \& Mishra 2012), committed, aid their organizations to maintain a competitive advantage and typically perform better (Rich et al., 2010; Whitman et al., 2010). In light of the strong need for high commitment in an evolving and progressively diversified workforce, a growing number of HRM research have concentrated on assessing the impact of high-performance work systems on employee engagement (Regy \& Malini, 2019; Huang et al., 2017; Abbassi et al., 2016).

In as much as a lot of researchers have accorded to the relationship between HPWS and Employee engagement, differences in geographical settings and cultures can either agree with this assertion or otherwise: the geographic background has shown that North America's employee engagement factors include work requirements, relationships with colleagues and superiors, incentives and acknowledgement; in East African country such as Kenya, the critical factors are employee growth, recognition and reward; in India job satisfaction, reward, communication, environment, work characteristics, culture and peer relations are some of the factors that lead to employee engagement (Kaur, 2017). It is therefore expedient to test this case in another geographical context, making Ghana being a West African country very appropriate for this study.

In spite of the linkages that researchers over the years have made about HPWS and Employee Engagement, there are some factors that can change the direction of the relationship of these two variables. One of such variables is Organizational Justice. Employees are social beings, bringing the need for the creation of favorable working environment that allows all workers to socially interact in a peaceful manner with equity and fairness taking a center stage: hence the need for organizational justice. From the day-to-day organizational activities such as the assignment of tasks, issues bothering on any sort of social exchange, a promotion decision, to even allocation of rewards, contention on the topic of fairness are meant to arise (Coetzee, as cited in Ghosh et al., 2014). Organizational justice therefore refers to the ethical, fair and just manner by which an organization treats its employees (Chou, 2009). The topic of organizational justice has carved a leading position in literature of itself. Some studies indicate that a greater sense of justice or fairness among employees can have a positive effect 
on different aspects of organizational behaviour such as: organizational commitment (Suliman \& Kathairi, 2013; Crow et al., 2012); job satisfaction (Chen McCain et al., 2010); employee performance (Suliman \& Kathairi, 2013; Wang et al., 2010); organizational citizenship behaviour (Muhammad, 2004); and most importantly due to this paper, employee engagement (Ghosh et al., 2014; Khuong \& Dung, 2015).

This study proposes that organizational justice which refers to the conceptions of workplace fairness among employees, may act as a potential moderating mechanism between perceived HPWS of employees and employee engagement. Even though previous studies have shown a relationship between employees perceived HPWS and employee engagement (Abbassi et al., 2016; Huang et al., 2017; Regy \& Malini, 2019), not much is known about how organizational justice could moderate the relationship between these two concepts. Therefore, the purpose of this study is to evaluate the Impact of HPWS on employee engagement in the Ghanaian context and also to ascertain if organizational justice could moderate the relationship between these two. This study goes further to explore how and why organizational justice can change the direction of employees' engagement even in the midst of implemented HPWS.

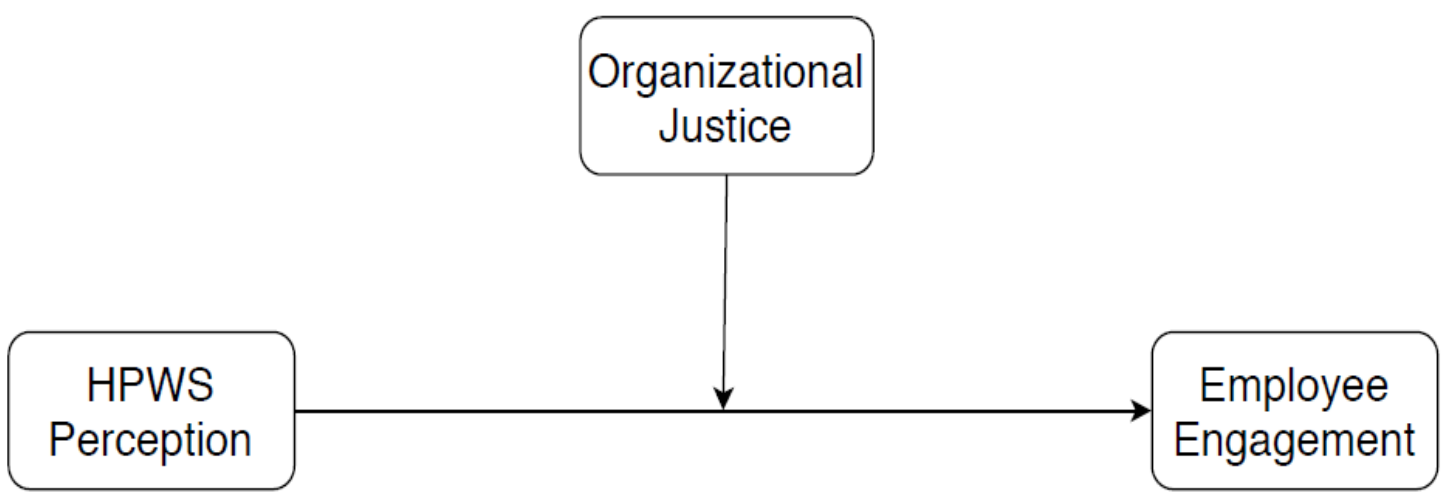

FIGURE 1. SIMPLIFIED CONCEPTUAL MODEL

Source: Conceptualization from Literature Reviewed

\section{THEORETICAL BACKGROUND AND HYPOTHESES}

\subsection{High Performance Work System and Employee Engagement}

High-performance work systems (HPWS) are described as groups of distinct but interconnected human resource activities intended to maximize the productivity of employees (Appelbaum et al., as cited in Arefin et al., 2019). These intertwined HR practices include but not limited to recruitment, selection, training and development, performance appraisal, promotional opportunities assessment, employee 
autonomy and participation, information sharing, and job security. Therefore, the application of HPWS leads to the development of employee skills and also serves as a motivating platform.

Employee Engagement is a field in organizational practice that has been situated within the topic of personnel management. However, it is generally being presented in other organizational contexts due to its effect on the operational performance of businesses (Bailey et al., as cited in Mahdi, 2014). Based on the research of Rich et al. (2010) which suggests with reference to Kahn's concept of job involvement that a continuous employment and manifestation of an individual's 'preferred self' in behavioral tasks that encourage that individual's connections to other coworkers and also to the work itself, as well as personal presence, can be segmented into physical, cognitive, and emotional. It must be noted that although some researchers have attempted to distinguish between work engagement, job engagement, employee or personal employment, fundamentally they all mean the same (Gupta \& Shukla, 2017). Therefore, any definition given by other others can be applied to any of the terms. Kahn as cited in Arefin et al. (2019) by using the term 'job engagement' defines the concept as the building of members of an organization; employing and expressing oneself mentally, emotionally and cognitively during the performance of one's roles.

According to Blau as cited in Arefin et al. (2019), social exchange theory depicts that people in a social exchange relationship are usually seen as emotional beings who attain information, process the information cognitively, and then goes to the next step of making decisions concerning the pattern and nature of exchange the employee has with his employer or organization for instance (Bal et al., 2013). Hence the process of exchange produces feelings and emotions that can lead people to assign certain emotions to different social structures, such as their organizations. Such emotional attributions, in effect, determine how deeply an individual feel attached to his or her organisation, which further affects the employees' engagement behavior and dedication to this relationship with the organization (Lawler, 2001). Based on the theory of social exchange, HPWS scholars believe that because HPWS focuses on promoting employee growth by enriching jobs, improving employee skills and facilitating participatory decision-making, HPWS will be responded by employees via increased job commitment and involvement with organizations which eventually will lead to a higher degree of engagement (Snape \& Redman, 2010; Bal et al., 2013). Similarly, when people participate in a partnership of social exchange and willingly behave for another person, they expect a future reciprocal gesture. Hence when a company for instance employs HPWS, workers will be required to return this investment through greater involvement, dedication and engagement. This assertion is therefore in line with the countless number of studies which support the relationship between HPWS and employee engagement. 
Summarily, via the social exchange theory, an employee is most likely to reciprocate in the affirmative through a positive work-related behavior when there is perception of organizational favor to him or her. Therefore, to the employee, the employment of HPWS shows the organization's care and investment for the employees and this motive the worker to show a favorable work-related behavior and attitude that benefits the organization. Several studies done elsewhere in the world have shown this positive relationship between HPWS and employee engagement (Muduli et al., 2016; Abbassi et al., 2016; Huang et al., 2017; Alfes et al., 2013; Mahdi, 2014; Regy \& Malini, 2019). Therefore, this study proposes that the HPWS increases employees' engagement.

Hypothesis 1: There is a positive relationship between Perceived High-performance Work systems (HPWS) and employee engagement.

\subsection{Moderating role of Organizational Justice and relationship with HPWS and Employee Engagement}

According to Randeree (2008) Organizational Justice has to do with treating employees fairly. This term depicts an individual's view of fairness of treatment meted out from the organization and the individual's behavioral reaction due to that perception (Fernandes, 2006). Organizational fairness or justice could include issue that have to do with fairness in remuneration, employee recruitment and selection process, and equal promotional opportunities (Tabibnia et al., 2008). Hence injustice in this setting is the unfairness in employee treatment: example unequal payment for different genders doing the same job.

Distributive justice, procedural justice and interactional justice are the three major elements of organizational justice. Whiles distributive justice is the fairness in terms of decision outcomes and resources distribution which could be either tangible or intangible, procedural justice has to do with the focus on the processes that are being used to determine or produce the outcomes. On the other hand, interactional justice emphasizes on the perception of employees concerning the interpersonal behavior applied whiles presenting procedures and decisions (Alvi \& Abbasi, 2012). These three components of organizational justice come together to make sure justice concerning the governing norms and rules leading to outcomes in terms of how rewarding and punishing ought to be distributed, the procedures to be used in making such a distribution decision, and finally how workers are to be treated interpersonally (Hayunintyas et al., 2018). Therefore, the way by which an employee if he or she has been fairly treated whiles undertaking duties at the place of work and the way such determination and perception affect other work-related components is what organizational justice is about.

Additionally, among the enlarging body of literature on human resource practices, the concept of HPWS has been agreed by various scholars as having a direct relationship with employee engagement: the 
higher the degree of HPWS employed, the higher the possibility of employees becoming more engaged in their work (Huang et al., 2017; Regy \& Malini, 2019; Muduli et al., 2016; Mahdi, 2014; Abbassi et al., 2016). As has been explained, HPWS are a set of separate but interconnected HR practices such as selection, training and development, compensation and the like, which have the ability to develop and motivate a workforce with the aim of achieving sustainable competitive advantage and perceived organizational performance (Way, 2002). Employee engagement on the other hand is the emotional or intellectual commitment an employee has towards his or her organization (Richman, 2006). Furthermore, the previous factors that were associated with employee engagement include self-efficacy, psychological empowerment, authentic leadership, organizational tenure, need for achievement and most importantly organizational justice (Ugwu et al., 2014; Arefin et al., 2019).

Therefore, drawing on the same social exchange theory which depicts the phenomenon of reciprocity, organizational justice with its 'fairness' attribute will have a positive relationship with HPWS and employee engagement and therefore should also be able to determine the relationship between them. Hence although with HPWS in place, employees' engagement level will depend on how fair they perceive their working environment: fairness will lead to more engagement whiles unfairness will lead to disengagement. In a nut shell, when an employee have a perception of a fair, just and equitable working treatment in the midst of favorable HR practices, that individual is likely to feel more obliged to reciprocate the conducive gesture provided by the employer by increasing his or her efforts in aiding the employer achieve the corporate goals (Williams et al., 2002; Inoue et al., 2009; Alvi \& Abbasi, 2012; Gupta \& Kumar, 2012; Strom et al., 2013; Ghosh et al., 2014). As a result, based on social exchange theory this study suggests that Organizational Justice is positively related to both HPWS and employee engagement whiles it plays a moderating role between the two as well.

Hypothesis 2: Organizational Justice moderates the relationship between high-performance work systems and employee engagement.

Hypothesis 3: There is a positive relationship between Organizational Justice and perceived Highperformance Work systems (HPWS)

Hypothesis 4: There is a positive relationship between Organizational Justice and Employee Engagement.

\section{METHODOLOGY}

\subsection{Data Collection and Sample}

The data was gathered from employees of Professional Service firms in two regions in Ghana. Whiles some part of the survey (majority) was web-based via reaching out to potential respondents by their 
emails due to covid-19 pandemic that made it difficult to get a hold of them at their work places, a few others mainly the junior staff were contacted directly due to their presence at their offices when the researcher visited their work places. Respondents were required to agree to partake in this study before completing the survey. Additionally, respondents were provided with related information and the researcher explained to them what the data was going to be used for. In all, out of a total of 300 questionnaires that were administered 274 were returned. However due to incompletion from 23 respondents, a final total of 251 were used for the analysis for this research. Hence all results in this research were attained from the primary research whiles the Statistical Package for the Social Sciences (SPSS) software version 21 was used to analyze the data gathered.

\subsection{Measures}

High-performance work systems: Employees' perception of HPWS was measured using a 24-item questionnaire which has been used in previous studies. Unlike other HPWS-itemed questionnaires that deals with six HR practices, the item used in this research had seven typical practices: Selection items from Sun et al. (2007) [e.g., "my organisation hires only the very best people for all potential vacancies"]; Training and Development items from Gould-Williams (2004) [e.g., "there are many training opportunities offered by my organisation to help me perform my job better"]; Performance-Based Compensation items from Zacharatos et al. (2005) [e.g., I am rewarded fairly for the amount of effort that I put in my job]; Promotional Opportunities items from Delery and Doty (1996) [e.g., "employees who desire promotion in this institution have more than one potential position they could be promoted to"]; Employee Autonomy and Participation items from Guthrie et al. (2009) [e.g., "my organisation allows me to plan how I do my work"]; Information Sharing items from Macky and Boxall (2007) [e.g., "the communication between me and other employees at work is good"]; Job Security items from Bae et al. (2003) [e.g., "employees can stay with this organisation as long as they wish"]. All these constructs were measured using a 5-point Likert scale type which ranged from Strongly Disagree (1) to Strongly Agree (5).

Organizational Justice: In terms of this variable, the corresponding Distributive, Procedural and Interactional Justice items were taken from the work of Neihoff et al. (1993). Examples of questions asked respondents were, 'I feel that my job responsibilities are quite fair' (under Distributive Justice); 'my manager/supervisor makes sure that all employee concerns are heard before Job decisions are made' (under Procedural Justice); 'concerning decisions made about my job, the manager/ supervisor discusses with me the implications of the decisions' (under Interactional Justice). Responses under this construct were also gotten using a 5-point Likert scale ranging from Strongly Disagree (1) to Strongly Agree (5). 
Employee Engagement: With a 5-point Likert scale which ranged from Strongly Disagree (1) to Strongly Agree (5), the items used to measure employee engagement in this study were slightly abridged from those developed by Rich et al. (2010). Therefore with regards to the three facets of engagement as was propounded by the developers, while the physical aspect (3-items) had a question like 'I am devoting a lot of my energy in my work', the emotional aspect (3-items) also had a question such as 'I am emotionally connected to my work' and the cognitive aspect of engagement (3-item) had a question like 'I concentrate completely when working'.

Control Variables: Due to the fact that variables such as gender, age and years of stay with a particular employment could be vital engagement predictors (Seibert et al., 2011; Schaufeli, 2012), these variables were therefore controlled.

\section{DATA RESULTS AND ANALYSIS}

\subsection{General}

This study purposed to assess the relationship between HPWS and employee engagement and also sought to find out if organizational justice moderates the relationship between these two variables. With the application of quantitative research questions, the researcher gathered data from 300 employees via a survey which was mainly web-based and mailed to them. Out of the 300 targeted employees, 274 responded bringing the response rate to $91 \%$. However, not all the 274 responses could be used because 23 respondents did not answer some of the questions in the questionnaire. Hence a total of 251 was rather used for the analysis of this paper. Out of the 251 participants, 117 were males, representing $46.6 \%$ and 134 were females representing $53.4 \%$. In terms of age: there were 16 respondents belonging to the age bracket of 15 to 24 years representing $6.4 \% ; 170$ respondents within the ages of 25 to 34 years which represents $67.7 \%$ (majority of respondents); and 65 respondents with ages in between 35 and 44 years representing $25.9 \%$ took part of this survey. Although there were other age brackets as options to respondents spanning all the way to even after retirement ages but none of the respondents choose those ages, signifying the relatively younger generation of the working class who participated in this survey. With regards to the number of years that respondents had worked in their organizations, the results were as follows: 38 respondents working for 1 year; 50 respondents working for 2 years; 29 respondents working for 3 years; 46 respondents working for 4 years; 19 respondents working for 5 years; 13 respondents working for 6 years; 8 respondents working for 7 years; 13 respondents working for 8 years; 17 respondents working for 9 years; 1 respondent working for 10 year; 4 respondents working for 11 years; another 4 respondents working for 12 years; 5 respondents working for 13 years; and 4 respondents working for 14 years in the same organization. 
With all 251 cases being valid and usable for analysis, the dataset has a Cronbach's Alpha of .718 signifying the internal consistency of how the set of data items are closely related.

\subsection{Testing Hypotheses}

4.2.1 Relationship between Perceived High-performance Work systems (HPWS) and employee engagement.

TABLE 1. CORRELATIONS AMONG STUDY VARIABLES

\begin{tabular}{|c|c|c|c|c|}
\hline & & HPWS & $\begin{array}{c}\text { Organizational } \\
\text { Justice }\end{array}$ & $\begin{array}{c}\text { Employee } \\
\text { Engagement }\end{array}$ \\
\hline \multirow[b]{3}{*}{ HPWS } & $\begin{array}{l}\text { Pearson } \\
\text { Correlation }\end{array}$ & 1 & $.426^{* *}$ & $.121^{*}$ \\
\hline & Sig. (1-tailed) & & .000 & .028 \\
\hline & $\mathrm{N}$ & 251 & 251 & 251 \\
\hline \multirow{3}{*}{$\begin{array}{l}\text { Organizational } \\
\text { Justice }\end{array}$} & $\begin{array}{l}\text { Pearson } \\
\text { Correlation }\end{array}$ & $.426^{* *}$ & 1 & .043 \\
\hline & Sig. (1-tailed) & .000 & & .251 \\
\hline & $\mathrm{N}$ & 251 & 251 & 251 \\
\hline \multirow{3}{*}{$\begin{array}{l}\text { Employee } \\
\text { Engagement }\end{array}$} & $\begin{array}{l}\text { Pearson } \\
\text { Correlation }\end{array}$ & $.121^{\star}$ & .043 & 1 \\
\hline & Sig. (1-tailed) & .028 & .251 & \\
\hline & $\mathrm{N}$ & 251 & 251 & 251 \\
\hline
\end{tabular}

**. Correlation is significant at the 0.01 level (1-tailed).

*. Correlation is significant at the 0.05 level ( 1 -tailed).

Source: Field Data, 2020

Table 1 displays the results of the Correlation analysis among the study variables. As presented in the table, a Pearson Correlation coefficient of .121 indicates that there is a positive association between HPWS and Employee Engagement. Although the Pearson r (.121) between these two variables does not show a very strong correlation, a significance figure of $.028(p<0.05)$ clearly depicts statistical significance. Hence the positivity of the Pearson $r$ as well as the $p$-value means there is a positive relationship between HPWS and Employee Engagement. Hypothesis one is therefore supported.

4.2.2 Organizational Justice moderating the relationship between high-performance work systems and employee engagement.

TABLE 2. REGRESSION ANALYSIS

TABLE 2A. MODEL SUMMARY

\begin{tabular}{|l|c|r|r|r|r|r|r|r|r|}
\hline \multirow{2}{*}{ Model } & \multirow{2}{*}{$\mathrm{R}$} & \multirow{2}{*}{$\mathrm{R}$ Square } & \multirow{2}{*}{$\begin{array}{l}\text { Adjusted } \mathrm{R} \\
\text { Square }\end{array}$} & $\begin{array}{l}\text { Std. Error of } \\
\text { the Estimate }\end{array}$ & $\begin{array}{l}\text { R Square } \\
\text { Change }\end{array}$ & F Change & df1 & df2 & $\begin{array}{l}\text { Sig. F } \\
\text { Change }\end{array}$ \\
\hline 1 & $.193^{\mathrm{a}}$ & .037 & .026 & .38801 & .037 & 3.193 & 3 & $247^{\mathrm{a}}$ & .024 \\
\hline
\end{tabular}

a. Predictors: (Constant), OrganJustXHPWS, HPWS, Organizational_Justice

Source: Field Data, 2020 
Oppong Peprah, E.

THE IMPACT OF HIGH-PERFORMANCE WORK SYSTEMS ON EMPLOYEE ENGAGEMENT: THE MODERATING ROLE OF ORGANIZATIONAL JUSTICE

TABLE 2B. ANOVAa

\begin{tabular}{|c|c|c|c|c|c|c|}
\hline \multicolumn{2}{|c|}{ Model } & $\begin{array}{l}\text { Sum of } \\
\text { Squares }\end{array}$ & df & $\begin{array}{l}\text { Mean } \\
\text { Square }\end{array}$ & $\mathrm{F}$ & Sig. \\
\hline \multirow[t]{3}{*}{1} & Regression & 1.442 & 3 & .481 & 3.193 & $.024^{b}$ \\
\hline & Residual & 37.187 & 247 & .151 & & \\
\hline & Total & 38.629 & 250 & & & \\
\hline
\end{tabular}

a. Dependent Variable: Employee_Engagement

b. Predictors: (Constant), OrganJustXHPWS, HPWS, Organizational_Justice

Source: Field Data, 2020

TABLE 2C. COEFFICIENTSa

\begin{tabular}{|c|c|c|c|c|c|c|}
\hline \multirow{2}{*}{\multicolumn{2}{|c|}{ Model }} & \multicolumn{2}{|c|}{$\begin{array}{l}\text { Unstandardized } \\
\text { Coefficients }\end{array}$} & $\begin{array}{l}\text { Standardized } \\
\text { Coefficients }\end{array}$ & \multirow[t]{2}{*}{$t$} & \multirow[t]{2}{*}{ Sig. } \\
\hline & & B & Std. Error & Beta & & \\
\hline \multirow[t]{4}{*}{1} & (Constant) & 7.273 & 1.681 & & 4.326 & .000 \\
\hline & HPWS & -.952 & .479 & -.671 & -1.988 & .048 \\
\hline & Organizational_Justice & -1.199 & .498 & -1.208 & -2.409 & .017 \\
\hline & OrganJustXHPWS & .337 & .140 & 1.703 & 2.410 & .017 \\
\hline
\end{tabular}

a. Dependent Variable: Employee_Engagement

Source: Field Data, 2020

Moderation here is a statistical interaction, which is suggesting that Organizational Justice is a variable that can be used to determine the relationship between HPWS and Employee Engagement. From Table 2c, the p-value of the moderating variable, 'OrganJustXHPWS' (combination of Organizational Justice and HPWS) is .017 $(p<0.05)$ which indicates a significant interaction and depicting a moderation effect. Hence, organizational justice moderates the relationship between HPWS and employee engagement, thereby supporting hypothesis 2 .

\subsubsection{Relationship between Organizational Justice and perceived High-performance Work systems}

From Table 1, it could be ascertained that Organizational Justice is positively related to HPWS [because $r=.426$ and $p(.000)<.05]$. This result supports hypothesis three.

\subsubsection{Relationship between Organizational Justice and Employee Engagement}

On the coefficients table (Table 2c), even though there is significant p-value of .017 depicting the relationship between Employee Engagement and Organizational Justice, the Unstandardized Coefficient of -1.199 means that for every unit of increase of Organizational Justice, it will cause a 1.199 decrease of Employee Engagement. This depicts a rather negative relationship between these two variables. This information therefore does not support Hypothesis 4. 


\subsubsection{General Fitness of Model}

A standard Error of .38801 (Table 2a) suggest the precision of this model. That is, there is a $38.8 \%$ chance of being wrong if someone uses this regression model to make estimate or make a prediction concerning the dependent variable which is employee engagement. Since this percentage is relatively very smaller, it further strengthens the fitness of this model. Most importantly, with regards to the statistical significance of the model, the ANOVA (Table 2b) confirms the main notion of this study, that the independent variable (HPWS) significantly statistically predict the dependable variable (Employee Engagement) since $p(.024)<.05$. This invariably signifies that the regression model is a good fit of the data. The fitness of this model can again be emphasized from Table $2 c$ (Coefficients): the $p$ values of both HPWS (.048) and Organizational Justice (.017) are less than .05, meaning they are all significant.

\section{DISCUSSIONS}

\subsection{Findings}

In line with the theory of social exchange, this study has presented with empirical evidence that there is a positive relationship between HPWS and Employee Engagement. This means that the show of care and investment in employees in the sense of employing HPWS and therefore ensuring a proper selection and recruitment program, investment in training and development of staff, establishing a performance-based compensation package, making available sizable promotional opportunities, ensuring employee autonomy and participation, making sure there is a conducive work atmosphere for information sharing and promoting job security goes a very long way into predicting employees' engagement, commitment and embeddedness in their jobs. This study further established a positive relationship between Organizational Justice and HPWS. A closer look at all the components of HPWS can lead one to perceive the issue of 'fairness' in all of them. For example, the provision of promotional opportunities will not mean anything to the employees if their perception of how others are promoted is considered unfair. Therefore, the presence of distributive, procedural and interactional justices enables an employed HPWS to succeed. As such, an increase in the perception of fairness and justice in the workplace can directly correlate to the increase of the success of employed HPWS.

This study was again able to put a firm footing on the suggested notion that Organizational Justice moderated the relationship between HPWS and employee engagement. This depicts that the introduction of organizational justice can determine the direction of the relationship that exist between HPWS and employee engagement. Although the presented model is significant and can predict employee engagement as initially suggested, the relationship between organizational justice and employee engagement is however negative. This therefore suggest that a higher level of fairness and 
justice in an organization decreases employee engagement and vice versa. In a nut shell, Organizational Justice is able to alter the association direction of HPWS and employee engagement.

\subsection{Theoretical Contribution}

This study has first of all provided a reference point in establishing the relationship between HPWS and employee engagement and the moderating role that organizational justice have in this relationship. This research makes a valuable contribution to the employee engagement, HPWS and strategic human resource management literature on the whole. One other unique contribution this study provides future researchers is the inverse direction that organizational justice provides in the relationship with employee engagement with empirical evidence as previous studies done on other geographical locations have unveiled the other way round. That is, by testing the moderating effect of organizational justice, this paper sheds light on how employee commitment and engagement can change in the midst of HPWS being established in an organization.

By the R-square value produced in model summary (Table 2a), this study has provided proof that there are other factors that can predict employee engagement. Therefore, this research will also affirm other researchers' works that add other predictors to HPWS to predict employee engagement as well as provide grounds for future research. This study has again established a positive relationship between HPWS and organizational justice which has not arrested researchers' attention at the moment. This study is hence encouraging scholars to conduct further studies to test other variables that can mediate the relationship between HPWS and organizational justice since there is no known study that has done that yet. Again, this research was done on an employee level, hence the perception of HPWS. It is therefore recommended that future research should use the same variables but consider the analysis at the firm level using HPWS execution. This should either confirm the results gotten at the employee level and if it does not, then a further cross-level research analysis will have to be also carried out in the later future afterwards.

Furthermore, this paper has shown how organizational justice weakens the positive relationship between HPWS and employee engagement. It is therefore suggested that future research should look at finding other moderating variables that can rather positivize and strengthen this relationship between HPWS and employee engagement.

\subsection{Practical Implications}

Practically, this study is vital to organizations because it furnishes them with the information about the importance of HPWS in improving employee commitment and engagement. Generally, this research 
has a lot of vital implications for organizations. Whiles other studies have affirmed same, this paper has added to make the voice louder that the implementation of HPWS is very important to the success of companies since they are able to make employees more embedded in their jobs. This study is also a reference point for practitioners that investment in HPWS is not a waste and therefore pays off and it also suggest to managers to pay out most attention during the implementation phase of HPWS in their organizations.

Although ensuring fairness and equity in an organization is good, if the reason for implementing HPWS is to achieve a stronger employee engagement in an organization, then this research is advising managers to make sure there is some level of unfairness in the administration of the HPWS components. This is the case because a higher level of fairness across board and organization-wide will only cause a higher number of employees to be disengaged. Therefore practically, the employment of human resource practices to some extent should be tailor-made and HR policies should be administered somehow differently by case by case bases if the firm is aiming at making employees entrenched in their job roles. Management should subsequently do away with a "one-size-fits-all" approach in administering HR policies if they wish to see more employees being committed to their work by considering individual differences. It should however be duly noted that this advice is purely for firms who are looking at employee commitment, embeddedness and engagement and not for organizations whose main focus is on something else (eg. profitability).

\subsection{Study Limitations and Future Research Directions}

As normally experienced with scientific researches, this study also has a number of limitations. Firstly, because data was only collected at the employee level, generalization even at the same organization is not possible due to the fact that this study only dealt with perception of HPWS and therefore HPWS executed at the firm level might give different results. The negative relationship between Organizational justice and employee engagement seen in this research as against the results of former studies might actually not be the case if the study was cross-sectional in nature which could have aided in the generalization of this result. Future research should therefore analyze these same variables at the firm level whiles another does a cross-sectional analysis to combine both firm and employee level to arrive at a more generalizable result. Furthermore, future research should find out if the findings of this study can be applicable in other organizations around the world aside West Africa where this study took place. As a similar study where data is gathered at the firm level is expected to arrive at a different finding, another future research potential should look at why the discrepancy between employee-perceived HPWS and management-executed HPWS. Another major limitation of this study is the researcher's inability to engage a lot more organizations to partake in this survey due to restricted movement as a 
result of the covid-19 pandemic. Hence employees of the various number of different professional service firms which the researcher initially targeted could not be reached. Future research should include majority of different professional service firms instead of having employees of two or more firms from the same industry, who has a possibility of giving similar data to be among the pool of respondents.

This research has proven that there are other predictors in addition to HPWS that can predict employee engagement. This study is therefore suggesting that future researchers can take it up and find the other predictors in addition to HPWS for employee engagement.

\section{CONCLUSION}

Drawing on the theory of social exchange, this research aimed at investigating the moderating role of organizational justice in the relationship between HPWS and employee engagement. This study ascertained that HPWS are intended to improve the productivity, effectiveness and commitment of employees. Therefore the Integration of HPWS such as a highly-prioritized and fair selective and recruitment process, rigorous training and development agenda, performance-based compensation, good promotional opportunities, employee autonomy and participation, conducive information sharing environment and enhanced job security in an organization's human resource management practices reflect the organization's good intentions in the treatment and investment in its human resources.

This paper has established the link between HPWS and employee engagement and has shown that the application of HPWS would enhance employee engagement which is essential for academicians in terms of future research considerations as well as to practitioners in terms of knowing the paths to take to make sure they get their employees embedded and entrenched in their job roles. However, employees' perception of fairness in treatment (organizational justice) has an inverse relationship with employee engagement. Meaning a one-standard-solution for all problems without bias or individual considerations in terms of HR policies and the systems forming the implemented HPWS will disengage the employees. This study has not only advanced literature on HPWS but also shown practitioners the need to implement tailor-made solutions to individual employees to gain their commitment.

\section{REFERENCES}

Abbassi, L., Zia-ur Rehman, M., \& Muhammad Javaid Iqbal, Y. (2016). Employee Engagement and High Performance Work System: An Empirical Study. Global Regional Review, I(I), 114-131. https://doi.org/10.31703/grr.2016(i-i).09 


\section{Oppong Peprah, E. \\ THE IMPACT OF HIGH-PERFORMANCE WORK SYSTEMS ON EMPLOYEE ENGAGEMENT: THE MODERATING ROLE OF ORGANIZATIONAL JUSTICE}

Alfes, K., Shantz, A., Truss, C., \& Soane, E. (2013). The link between perceived human resource management practices, engagement and employee behaviour: a moderated mediation model. The International Journal Of Human Resource Management, 24(2): 330-351. https://doi.org/10.1080/09585192.2012.679950

Alvi, A., \& Abbasi, A. (2012). Impact of organizational justice on employee engagement in banking sector of Pakistan. Middle-East Journal of Scientific Research, 12(5): 643-649.

Arefin, M., Alam, M., Islam, M., \& Rahaman, M. (2019). High-performance work systems and job engagement: The mediating role of psychological empowerment. Cogent Business \& Management, 6(1). https://doi.org/10.1080/23311975.2019.1664204

Bae, J., Chen, S., David Wan, T., Lawler, J., \& Walumbwa, F. (2003). Human resource strategy and firm performance in Pacific Rim countries. The International Journal Of Human Resource Management, 14(8), 1308-1332. https://doi.org/10.1080/0958519032000145774

Bal, P., Kooij, D., \& De Jong, S. (2013). How Do Developmental and Accommodative HRM Enhance Employee Engagement and Commitment? The Role of Psychological Contract and SOC Strategies. Journal Of Management Studies, 50(4): 545-572. https://doi.org/10.1111/joms. 12028

Chou, R.J.A. (2009). Organizational justice and turnover intention: a study of direct care workers in assisted living facilities for older adults in the United States. Social Development Issues, 31(1): 6985.

Crow, M., Lee, C., \& Joo, J. (2012). Organizational justice and organizational commitment among South Korean police officers. Policing: An International Journal of Police Strategies \& Management, 35(2): 402-423. https://doi.org/10.1108/13639511211230156

Delery, J., \& doty, D. (1996). Modes of theorizing in strategic human resource management: tests of universalistic, contingency, and configurations. Performance predictions. Academy of Management Journal, 39(4), 802-835. https://doi.org/10.2307/256713

Demirbag, M., Collings, D., Tatoglu, E., Mellahi, K., \& Wood, G. (2014). High-Performance Work Systems and Organizational Performance in Emerging Economies: Evidence from MNEs in Turkey. Management International Review, 54(3): 325-359. https://doi.org/10.1007/s11575-0140204-9

Fernandes, C. (2006). Impact of organisational justice in an expatriate work environment. Management Research News, 29(11): 701-712. https://doi.org/10.1108/01409170610716016

Ghosh, P., Rai, A., \& Sinha, A. (2014). Organizational justice and employee engagement. Personnel Review, 43(4): 628-652. https://doi.org/10.1108/pr-08-2013-0148

Gould-Williams, J. (2004). The Effects of 'High Commitment' HRM Practices on Employee Attitude: The Views of Public Sector Workers. Public Administration, 82(1): 63-81. https://doi.org/10.1111/j.0033-3298.2004.00383.x

Gupta, M., \& Shukla, K. (2017). An Empirical Clarification on the Assessment of Engagement at Work. Advances In Developing Human Resources, 20(1): 44-57. https://doi.org/10.1177/1523422317741692

Gupta, V., \& Kumar, S. (2012). Impact of performance appraisal justice on employee engagement: a study of Indian professionals. Employee Relations, 35(1): 61-78. https://doi.org/10.1108/01425451311279410 
Guthrie, J., Flood, P., Liu, W., \& MacCurtain, S. (2009). High-performance work systems in Ireland. International Journal of Human Resource Management, 20(1): 112-125.

Hayunintyas, R., Do, B., Sudiro, A., \& Irawanto, D. (2018). Organizational Justice and Effective Organizational Commitment mediated by Organizational Trust and Perceived Organizational Support: Study at the largest Poultry Industry Company in Indonesia. Asia Pacific Management And Business Application, 6(3): 175-196. https://doi.org/10.21776/ub.apmba.2018.006.03.4

Huang, Y., Ma, Z., \& Meng, Y. (2017). High-performance work systems and employee engagement: empirical evidence from China. Asia Pacific Journal Of Human Resources, 56(3): 341-359. https://doi.org/10.1111/1744-7941.12140

Inoue, A., Kawakami, N., Ishizaki, M., Shimazu, A., Tsuchiya, M., \& Tabata, M. et al. (2009). Organizational justice, psychological distress, and work engagement in Japanese workers. International Archives Of Occupational And Environmental Health, 83(1): 29-38. https://doi.org/10.1007/s00420-009-0485-7

Kaur, S. (2017). Antecedents and consequences of employee engagement: A literature review. IUP Journal of Organizational Behavior, 16(3): 7-32.

Khuong, M., \& Dung, D. (2015). The Effect of Ethical Leadership and Organizational Justice on Employee Engagement - The Mediating Role of Employee Trust. International Journal Of Trade, Economics And Finance, 6(4): 235-240. https://doi.org/10.7763/ijtef.2015.v6.475

Lawler, E. (2001). An Affect Theory of Social Exchange. American Journal Of Sociology, 107(2): 321352. https://doi.org/10.1086/324071

Macky, K., \& Boxall, P. (2007). The relationship between 'high-performance work practices' and employee attitudes: an investigation of additive and interaction effects. The International Journal Of Human Resource Management, 18(4): 537-567. https://doi.org/10.1080/09585190601178745

Mahdi, S. M. (2014). The Impact of High Performance Work System (HPWS) on Employee Productivity as Related to Organizational Identity and Job Engagement. European Journal of Business and Management, 6(39).

Chen McCain, S., Tsai, H., \& Bellino, N. (2010). Organizational justice, employees' ethical behavior, and job satisfaction in the casino industry. International Journal Of Contemporary Hospitality Management, 22(7): 992-1009. https://doi.org/10.1108/09596111011066644

Muduli, A., Verma, S., \& Datta, S. (2016). High Performance Work System in India: Examining the Role of Employee Engagement. Journal Of Asia-Pacific Business, 17(2): 130-150. https://doi.org/10.1080/10599231.2016.1166021

Muhammad, A. (2004). Procedural justice as mediator between participation in decision-making and organization citizenship behavior. International Journal Of Commerce And Management, 14(3/4), 58-68. https://doi.org/10.1108/10569210480000184

Randeree, K. (2008). Organisational Justice: Migrant Worker Perceptions in Organisations in the United Arab Emirates. Journal Of Business Systems, Governance And Ethics, 3(4). https://doi.org/10.15209/jbsge.v3i4.148

Regy, J., \& Malini, D. (2019). Impact of High Performance Work Practices on Employee Engagement in Apparel Manufacturing and Retail Firms. Prabandhan: Indian Journal Of Management, 12(2): 7. https://doi.org/10.17010/pijom/2019/v12i2/141753 
Rich, B., Lepine, J., \& Crawford, E. (2010). Job Engagement: Antecedents and Effects on Job Performance. Academy Of Management Journal, 53(3): 617-635. https://doi.org/10.5465/ami.2010.51468988

Richman, A. (2006). Everyone wants an engaged workforce how can you create it? Workspan, 49(1): 36-39.

Sahoo, C., \& Mishra, S. (2012). A framework towards employee engagement: The PSU experience. ASCl Journal of Management, 42(1): 92-110.

Schaufeli, W. B. (2012). Work engagement. What do we know and where do we go? Romanian Journal of Applied Psychology, 14, 3-10.

Seibert, S., Wang, G., \& Courtright, S. (2011). Antecedents and consequences of psychological and team empowerment in organizations: A meta-analytic review. Journal Of Applied Psychology, 96(5): 981-1003. https://doi.org/10.1037/a0022676

Snape, E., \& Redman, T. (2010). HRM Practices, Organizational Citizenship Behaviour, and Performance: A Multi-Level Analysis. Journal Of Management Studies. https://doi.org/10.1111/j.1467-6486.2009.00911.x

Strom, D., Sears, K., \& Kelly, K. (2013). Work Engagement. Journal Of Leadership \& Organizational Studies, 21(1): 71-82. https://doi.org/10.1177/1548051813485437

Suliman, A., \& Al Kathairi, M. (2012). Organizational justice, commitment and performance in developing countries. Employee

Relations, 35(1):

98-115.

https://doi.org/10.1108/01425451311279438

Sun, L., Aryee, S., \& Law, K. (2007). High-Performance Human Resource Practices, Citizenship Behavior, and Organizational Performance: A Relational Perspective. Academy Of Management Journal, 50(3): 558-577. https://doi.org/10.5465/amj.2007.25525821

Tabibnia, G., Satpute, A., \& Lieberman, M. (2008). The Sunny Side of Fairness. Psychological Science, 19(4), 339-347. https://doi.org/10.1111/j.1467-9280.2008.02091.x

Ugwu, F., Onyishi, I., \& Rodríguez-Sánchez, A. (2014). Linking organizational trust with employee engagement: the role of psychological empowerment. Personnel Review, 43(3): 377-400. https://doi.org/10.1108/pr-11-2012-0198

Wang, X., Liao, J., Xia, D., \& Chang, T. (2010). The impact of organizational justice on work performance. International Journal Of Manpower, 31(6): 660-677. https://doi.org/10.1108/01437721011073364

Way, S. (2002). High Performance Work Systems and Intermediate Indicators of Firm Performance Within the US Small Business Sector. Journal Of Management, 28(6): 765-785. https://doi.org/10.1177/014920630202800604

Whitman, D., Van Rooy, D., \& Viswesvaran, C. (2010). Satisfaction, Citizenship Behaviors, And Performance In Work Units: A Meta-Analysis Of Collective Construct Relations. Personnel Psychology, 63(1) : 41-81. https://doi.org/10.1111/j.1744-6570.2009.01162.x

Williams, S., Pitre, R., \& Zainuba, M. (2002). Justice and Organizational Citizenship Behavior Intentions: Fair Rewards Versus Fair Treatment. The Journal Of Social Psychology, 142(1): 33-44. https://doi.org/10.1080/00224540209603883 
Wu, N., Hoque, K., Bacon, N., \& Bou Llusar, J. (2015). High-performance work systems and workplace performance in small, medium-sized and large firms. Human Resource Management Journal, 25(4): 408-423. https://doi.org/10.1111/1748-8583.12084

Zacharatos, A., Barling, J., \& Iverson, R. (2005). High-Performance Work Systems and Occupational Safety. Journal Of Applied Psychology, 90(1): 77-93. https://doi.org/10.1037/0021-9010.90.1.77 